\title{
Long-term trends of chemical characteristics and sources of fine particle in Foshan City, Pearl River Delta: 2008-2014
}

\author{
Jihua Tan ${ }^{\mathrm{a}, \mathrm{c}, \mathrm{e}}$, Jingchun Duan ${ }^{\mathrm{b}, \mathrm{c}}$, Yongliang Ma ${ }^{\mathrm{c}, *}$, Kebin $\mathrm{He}^{\mathrm{c}}$, Yuan Cheng ${ }^{\mathrm{c}}$, Si-xin Deng ${ }^{\mathrm{d}}$, \\ Yan-ling Huang ${ }^{\mathrm{d}}$, Shu-ping Si-Tu ${ }^{\mathrm{d}}$ \\ ${ }^{a}$ Huairou Eco-Environmental Observatory, College of Resources and Environment, University of Chinese Academy of Sciences, Beijing 100049, China \\ b State Key Laboratory of Environmental Criteria and Risk Assessment, Chinese Research Academy of Environmental Sciences, Beijing 100012, China \\ c School of Environment, Tsinghua University, Beijing 100084, China \\ d Foshan Environmental Protection Bureau, Foshan 528000, China \\ e Research Centre for Eco-Environmental Sciences, Chinese Academy of Sciences, Beijing 100085, China
}

\section{H I G H L I G H T S}

- Seven-years long characteristic of chemical and source of $\mathrm{PM}_{2.5}$ were investigated

- $\mathrm{PM}_{2.5}$ and most of chemical species decreased significantly from 2008 to 2014

- Sulfate and OC were the most important chemical species in 2008 and 2014

- Primary sources decreased significantly, but secondary sources increased.

- Continuous monitoring is an adequate strategy for air quality control policy

\section{A R T I C L E I N F O}

\section{Article history:}

Received 5 May 2015

Received in revised form 19 April 2016

Accepted 9 May 2016

Available online 16 May 2016

Editor: D. Barcelo

\section{Keywords:}

Long-term

Source apportionment

$\mathrm{PM}_{2.5}$

Chemical species

Pearl River delta
GRAPH ICA L A B S T R A C T

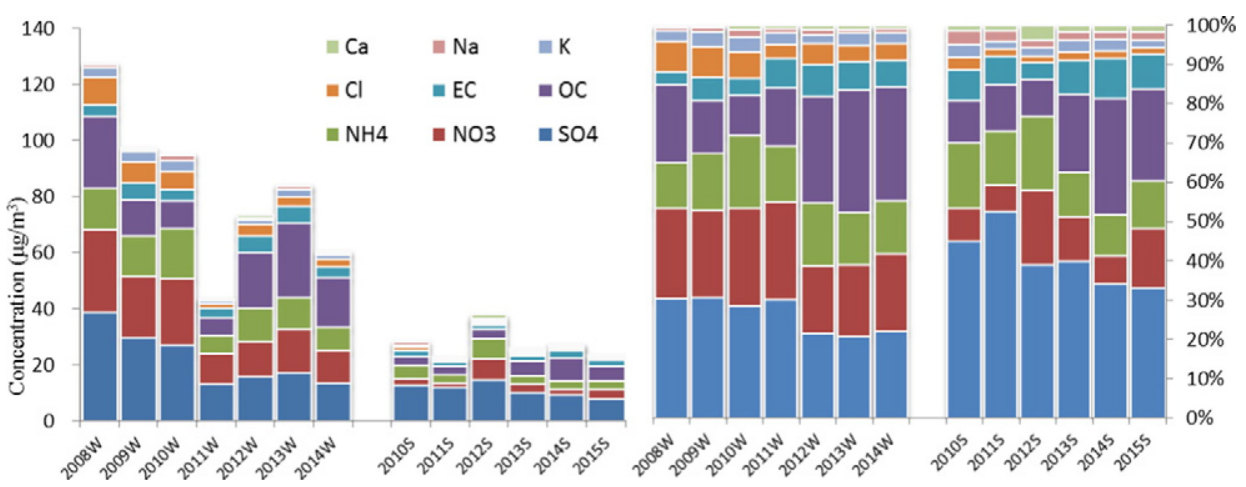

\begin{abstract}
A B S T R A C T
Foshan is a major international ceramic center and the most polluted city in the Pearl River Delta (PRD). Here we present the results of the first long-term $\mathrm{PM}_{2.5}$ (particles $<2.5 \mu \mathrm{m}$ ) sampling and chemical characterization study of the city. A total of 2774 samples were collected at six sites from 2008 to 2014, and analyzed for water soluble species, elements and carbonaceous species. The major constituents of $\mathrm{PM}_{2.5}$ were sulfate, OC (Organic Carbon), nitrate, ammonium and EC (Elemental Carbon), which accounted for 50\%-88\% of $\mathrm{PM}_{2.5} . \mathrm{PM}_{2.5}$ and the most abundant chemical species decreased from 2008 to 2011, but rebounded in 2012-2013. After 2008, the chemical composition of $\mathrm{PM}_{2.5}$ changed dramatically due to the implementation of pollution control measures. From 2008 to $2011, \mathrm{SO}_{4}^{2-}$ and $\mathrm{NO}_{3}^{-}$were the two largest components; subsequently, however, OC was the largest component. The respective contributions of $\mathrm{SO}_{4}^{2-}, \mathrm{NO}_{3}^{-}$and $\mathrm{OC}$ to the sum of water soluble species and carbonaceous species were $30.5 \%, 22.9 \%$ and $19.9 \%$ in 2008; and $20.2 \%, 16.5 \%$ and $30.2 \%$ in 2014. Distinct differences in nitrate and sulfate, and in mass ratio $\left[\mathrm{NO}_{3}^{-}\right] /\left[\mathrm{SO}_{4}^{2-}\right]$ imply that mobile sources tended to more important in Foshan during 2012-2014. The results indicate that pollution control measures implemented during 2008-2014 had a large effect on anthropogenic elements $(\mathrm{Pb}, \mathrm{As}, \mathrm{Cd}, \mathrm{Zn}$ and $\mathrm{Cu})$ and water soluble species, but little influence on crustal elements (V, Mn, Ti, Ba and Fe) and carbonaceous species. The PMF method was used for source apportionment of $\mathrm{PM}_{2.5}$. Industry (including the ceramic industry and coal combustion), vehicles and dust were the three most
\end{abstract}

\footnotetext{
* Corresponding author at: State Key Joint Laboratory of Environment Simulation and Pollution Control, School of Environment, Tsinghua University, Beijing 100084, China. E-mail address: Liang@tsinghua.edu.cn (Y. Ma).
} 
important sources and comprised $39.2 \%, 20.0 \%$ and $18.4 \%$ of $\mathrm{PM}_{2.5}$ in 2008 , respectively. However, secondary aerosols, vehicles and industry were the three most important sources and comprised $29.5 \%, 22.4 \%$ and $20.4 \%$ of $\mathrm{PM}_{2.5}$ in 2014, respectively. During the seven year study interval, the contributions of primary sources (industry and dust) decreased significantly, but secondary sources increased dramatically. Industry, dust and vehicles contributed $36.6 \mu \mathrm{g} \mathrm{m}^{-3}, 13.9 \mu \mathrm{g} \mathrm{m}{ }^{-3}$, and $9.2 \mu \mathrm{g} \mathrm{m}^{-3}$ to the reduction of $\mathrm{PM}_{2.5}$, respectively.

(c) 2016 Elsevier B.V. All rights reserved.

\section{Introduction}

In recent years there has been growing concern about the impact of air pollution in China, with the emphasis shifting from pollution on a local scale to that on a regional and larger scale. Fine particle is the primary pollutant of concern in the context of regional and complex air pollution in China (Chan and Yao, 2008), although rising NOx and high $\mathrm{O}_{3}$ are also causes for concern. $\mathrm{PM}_{2.5}$ has long been associated with adverse health impacts such as respiratory disease and increased mortality (Gens et al., 2014; Hagerman et al., 2014; Lin et al., 2014). Recent interest has focused on the chemical species, transformation and sources (Cao et al., 2003; Chan and Yao, 2008; He et al., 2001; Tan et al., 2009a, 2009b; Tang et al., 2006; Yang et al., 2011b) of $\mathrm{PM}_{2.5}$ since it is both an air pollutant and also has climatic implications; moreover, the mechanisms of formation, evolution, as well as their quantification, are complex (Duan et al., 2007; Liu et al., 2008; Querol et al., 2008; Sun et al., 2006; Wang et al., 2002; Yang et al., 2011a).

In recent years, many studies have investigated the level, temporal and spatial variation, transformation and sources of chemical species of $\mathrm{PM}_{2.5}$ (Cao et al., 2003, 2004; Duan and Tan, 2013; Duan et al., 2007; Keene et al., 2014; Querol et al., 2008; Tan et al., 2009a, 2009b). Zhang and Friedlander (2000) compared the inorganic elements databases for $\mathrm{PM}_{2.5}$ during 1980-1993 in China. Chan and Yao (2008) reviewed the chemical composition of $\mathrm{PM}_{2.5}$ across China with a focus on Metropolitan Regions. Chemical species and the reconstructed speciation of $\mathrm{PM}_{2.5}$ were compared in representative Chinese megacities in order to characterize $\mathrm{PM}_{2.5}$ (Yang et al., 2011b). However, many of the studies were based on small samples and observations were of short duration, making source apportionment and reliable trend analysis difficult. Systematic and long term observations of fine particle and their composition are critical for understanding their sources, transport and transformation processes, which in turn are essential for the formulation of effective air quality management strategies.

Foshan is located in the hinterland of the Pearl River Delta (PRD) in central Guangdong Province. It is the third largest city in the PRD, a major manufacturing center and one of the most important built-up areas in China. The key industries in Foshan include ceramics, nonmetal ore processing, and manufacturing including household electrical appliances and furniture. Most of these industries are highly polluting; for example, in 2008 the ceramic plants in Foshan account for around $30 \%$ of total world ceramics production and they consumed about $40 \%$ of the coal used in Foshan (Shen and Wei, 2012). These industries emit large amounts of pollutants into the atmosphere, and they have led to a rapid deterioration in air quality in and around the region. According to the Pearl River Delta Regional Air Quality Monitoring Network, $\mathrm{SO}_{2}, \mathrm{NO}_{\mathrm{x}}$ and $\mathrm{PM}_{10}$ (particulate matter $<10 \mu \mathrm{m}$ in diameter) in Foshan city are significantly higher than in other areas of the PRD.

In order to improve the air quality and thus public health, since 2007 the government has implemented a wide range of measures to reduce emissions from vehicles, power plants, and industrial and commercial processes. However, the primary emphasis of control measures has varied greatly from year to year. Here we present the results of an investigation of $\mathrm{PM}_{2.5}$ in Foshan from 2008 to 2014, which was supported by the Chinese government. The interval of study overlaps with the implementation of major air pollution control measures in Foshan city. $\mathrm{PM}_{2.5}$ samples were collected simultaneously at downtown, urban and rural sites with the aims of: 1) investigating their characteristics, trends and sources; 2 ) evaluating the impact of air quality policy on the chemical composition of $\mathrm{PM}_{2.5}$; and 3) producing emission control policy suggestions for $\mathrm{PM}_{2.5}$ in Foshan.

\section{Environmental materials and methods}

\subsection{Field observations}

Foshan is one of the most populated areas in the Pearl River Delta region in south China and one of the largest manufacturing bases in the world (Tan et al., 2014b). The terrain of Foshan is generally flat, and is surrounded by mountains from three directions; thus stagnant air conditions are frequent over the area and polluted air is not readily dispersed. Six sampling sites were chosen for study (Table 1) and the sampling network descriptions are as follows.

The Downtown site (CC) was situated at about $35 \mathrm{~m}$ above ground level in the Foshan Environmental Monitoring Centre, ChanCheng district; it is surrounded by four main roads, residential buildings and business offices. Four urban sites, SS, NH, SD and GM, were located in the Environmental Monitoring Station of SanShui district, NanHai district, ShunDe district and GaoMing district, respectively. These sites are representative of the residential and commercial environment of the urban area in the vicinity of the $\mathrm{CC}$ site. A rural site was selected at GengHe town in GaoMing district ( $\mathrm{GH}$ ), about $45 \mathrm{~km}$ from the downtown area of Foshan city. $\mathrm{PM}_{10}, \mathrm{SO}_{2}$ and $\mathrm{NO}_{2}$ were continuously monitored automatically by the Environment Protection Bureau of Foshan. Meteorological data were downloaded from Wunderground (www. wunderground.com).

The 24-h $\mathrm{PM}_{2.5}$ samples were collected on quartz filters (PALL 2500QAT-UP) using median-volume samplers ( $100 \mathrm{~L} / \mathrm{min})$. The sampling was performed from November 2008 to December 2014 at the six sites simultaneously (Fig. 1 ), yielding a total of $2774 \mathrm{PM}_{2.5}$ samples (Table 1). All quartz filters were annealed at $450{ }^{\circ} \mathrm{C}$ for $4 \mathrm{~h}$ to remove trace organics before use. Before and after collection, the filters were wrapped in baked aluminum foil. The mass of $\mathrm{PM}_{2.5}$ was determined by weighing the filters before and after exposure. Prior to weighing, the filters were stored in conditions of constant temperature and humidity $\left(25{ }^{\circ} \mathrm{C}\right.$ and $50 \%$ ) for $24 \mathrm{~h}$. After weighing, the samples were wrapped in aluminum foil and stored at $-30^{\circ} \mathrm{C}$ until analysis.

Table 1

The number of $\mathrm{PM}_{2.5}$ samples collected in Foshan city from 2008 to 2014.

\begin{tabular}{|c|c|c|c|c|c|c|}
\hline \multirow{2}{*}{ Sampling site } & ChanCheng & NanHai & SanShui & ShunDe & GaoMing & GengHe \\
\hline & $\mathrm{CC}$ & $\mathrm{NH}$ & SS & SD & GM & $\mathrm{GH}$ \\
\hline 2008 winter & 29 & 31 & 32 & 28 & 29 & \\
\hline 2009 winter & 32 & 30 & 31 & 32 & 29 & 28 \\
\hline 2010 summer & 45 & 42 & 39 & 40 & 41 & 46 \\
\hline 2010 winter & 51 & 45 & 46 & 44 & 39 & 45 \\
\hline 2011 summer & 40 & 42 & 38 & 45 & 37 & 44 \\
\hline 2011 winter & 53 & 44 & 43 & 45 & 41 & 43 \\
\hline 2012 summer & 38 & 36 & 42 & 43 & 38 & 36 \\
\hline 2012 winter & 50 & 46 & 45 & 47 & 43 & 45 \\
\hline 2013 summer & 45 & 44 & 43 & 46 & 43 & 46 \\
\hline 2013 winter & 49 & 46 & 44 & 46 & 40 & 46 \\
\hline 2014 summer & 16 & 17 & 16 & 15 & 16 & 15 \\
\hline 2014 winter & 45 & 43 & 45 & 41 & 42 & 47 \\
\hline Sum & 493 & 466 & 464 & 472 & 438 & 441 \\
\hline Total & & & 27 & & & \\
\hline
\end{tabular}




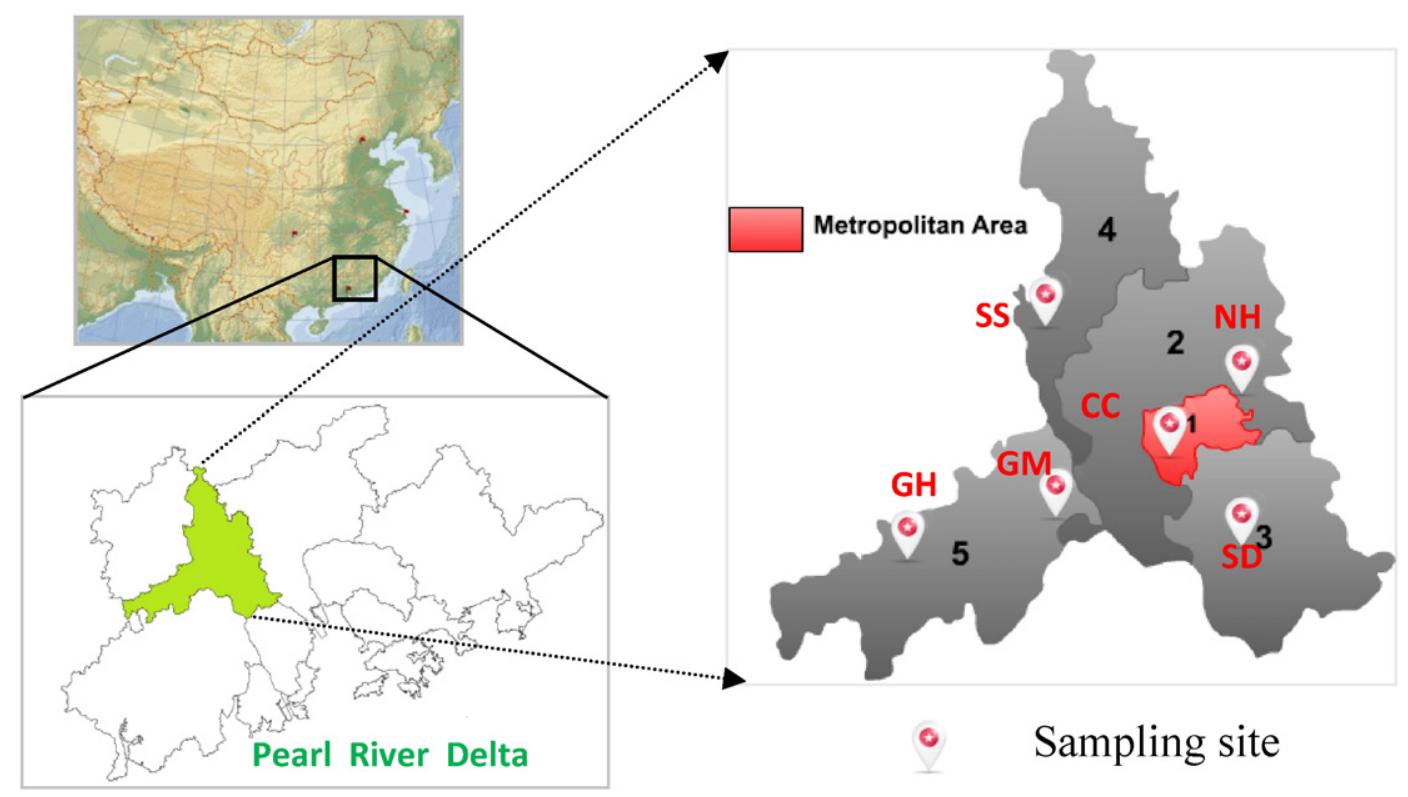

Fig. 1. Map of the sampling sites in Foshan city. (1: ChanCheng district; 2: NanHai district; 3: ShunDe district; 4: SanShui district; 5: GaoMing district).

\subsection{Chemical analyses}

\subsubsection{Element analyses}

A small portion of each filter was cut with stainless steel scissors and placed in Teflon tubes with a $4 \mathrm{~mL}$ mixture of concentrated hydrochloric acid and nitric acid with a ratio of 3:1 by volume, and then microwaved for $58 \mathrm{~min}$ to ensure the complete digestion of particles. Blank filters (a filter that was transported to the sampling site and installed in the sampler without sampling) and sample replicates were randomly inserted for quality control. Then, the digested solution was diluted to a volume of $10 \mathrm{ml}$ using ultra-pure water (specific resistance $\geq 18.3 \mathrm{M} \Omega \mathrm{cm}$ ) prior to analysis by inductively coupled plasma-mass spectrometry (ICP-MS) (Thermo, X serial) and ICP-AES (Thermo; IRIS Intrepid II XSP). The calibration was made using multi-element (metal) standards (certified reference materials (CRMs) provided by the National Analysis Center for Iron and Steel, China) in a $3 \%(\mathrm{v} / \mathrm{v}) \mathrm{HNO}_{3}$ solution.

Quartz filters are unsuitable for the analysis of certain elements. Al and Ca were not included in the analysis and only elements with low uncertainties are included in the present paper. Six blank filters were treated and analyzed in the same way as the actual samples. The detection limits (units: $\mu \mathrm{g} \mathrm{L}^{-1}$ ) were $\mathrm{Ti}$ (3.16), $\mathrm{Zn}(10), \mathrm{V}(0.5), \mathrm{Mn}$ (1.50), Cu (1.47), As (0.38), Cd (0.03), Ba (1.75), Tl (0.006), Pb (5.88), Fe (11.32) and $\mathrm{Bi}(0.33)$.

\subsubsection{Organic and Elemental Carbon (OC/EC)}

OC and EC were analyzed using a DRI Model 2001 thermal/optical carbon analyzer following the IMPROVE protocol. Samples were heated stepwise to produce OC fractions (OC1, OC2, OC3 and OC4 at $140{ }^{\circ} \mathrm{C}$, $280{ }^{\circ} \mathrm{C}, 480{ }^{\circ} \mathrm{C}$ and $580{ }^{\circ} \mathrm{C}$, respectively, in a helium atmosphere); OP (a pyrolyzed carbon fraction); and EC fractions (EC1, EC2, and EC3 at $580{ }^{\circ} \mathrm{C}, 740{ }^{\circ} \mathrm{C}$ and $840{ }^{\circ} \mathrm{C}$, respectively, in a $2 \% \mathrm{O}_{2} / 98 \%$ He atmosphere). OC is defined as OC1 + OC2 + OC3 + OC4 + OP and EC is defined as EC1 + EC2 + EC3-OP (Cheng et al., 2010; Chow et al., 2007). The analyzer was calibrated daily with $\mathrm{CH}_{4}$. Procedural blanks with field samples were used to quantify detection limits. The blank-based limits of detection (LOD), calculated for each species as three times the average field blanks, were both below $1.0 \mu \mathrm{g} \mathrm{m}^{-3}$ for OC and EC. Replicate analyses were performed at the rate of one per group of 10 samples. The repeatability determined was better than $5 \%$.

\subsubsection{Water-soluble inorganic ions}

Ion chromatography (Dionex 1400) was used to determine the concentrations of inorganic ions. The concentrations of the water-soluble inorganic ions in the field blanks (a filter that was transported to the sampling site and installed in the sampler without sampling) were $0.07,0.08$, not detected (nd), 0.16 , nd, 0.12 , nd, 0.05 and $0.08 \mu \mathrm{g} \mathrm{m}^{-3}$ for $\mathrm{F}^{-}, \mathrm{Cl}^{-}, \mathrm{NO}_{3}^{-}, \mathrm{SO}_{4}^{2-}, \mathrm{NH}_{4}^{+}, \mathrm{Na}^{+}, \mathrm{K}^{+}, \mathrm{Ca}^{2+}$ and $\mathrm{Mg}^{2+}$, respectively. The relative standard deviation of each ion was $<6 \%$ for the reproducibility test. Details of the analysis procedures for inorganic elements, carbonaceous species and water soluble inorganic species, are presented elsewhere (Duan et al., 2014; Tan et al., 2009a).

\subsubsection{PMF analysis}

The PMF model was developed by Paatero and Tapper (1994) and Paatero (2004). EPA PMF is one of the receptor models developed by the US EPA's Office of Research and Development (ORD). The algorithms used in the EPA PMF model to compute profiles and contributions have been peer reviewed by leading scientists in the air quality management community and have been certified as scientifically robust. In this study, OC, EC, 15 elements and 8 ions were included in the EPA PMF 3.0 model. The input data include chemical species and equation-based uncertainties. The equation-based uncertainty included detection limits and error fractions (5\%). If the concentration is less than or equal to the method detection limit (MDL) provided, the uncertainty (Unc) is calculated using the following equation (Polissar et al., 1998).

Unc $=\frac{5}{6} \times \mathrm{MDL}$.

If the concentration is greater than the MDL provided, the calculation is

Unc $=\sqrt{(\text { Error Fraction } \times \text { concentration })^{2}+(\mathrm{MDL})^{2}}$.

\section{Results}

\subsection{Temporal variation of chemical species of $P M_{2.5}$}

\subsubsection{Temporal variation of $P M_{2.5}$}

As can be seen in Fig. 2, $\mathrm{PM}_{2.5}$ in Foshan remained rather high from 2008 to 2014, and the average concentration of $\mathrm{PM}_{2.5}$ (113.1 \pm 
$48.1 \mu \mathrm{g} \mathrm{m}^{-3}$ ) during the seven year measurement interval was almost twice the average daily value of $65 \mu \mathrm{g} \mathrm{m}{ }^{-3}$ recommended by national ambient air quality standards (NAAQS 2012). PM $_{2.5}$ was highly variable, with minimum and maximum values of $4.0 \mu \mathrm{g} \mathrm{m}^{-3}$ and $601.8 \mu \mathrm{g} \mathrm{m}^{-3}$. The highest and lowest daily mean concentrations were observed in January 2008 and January 2011, respectively. Low levels of $\mathrm{PM}_{2.5}$ were observed during days when a high speed wind was associated with winds from remote North China, which typically occurred in winter. The highest levels of $\mathrm{PM}_{2.5}$ were observed in haze days when air masses came from northeast of the PRD (Tan et al., 2014b). However, it is noteworthy that the concentration of $\mathrm{PM}_{2.5}$ decreased from 2008 to 2011, rebounded in 2012-2013, and decreased sharply in 2014.

\subsubsection{Temporal variation of water soluble species}

The concentrations of water soluble species in Foshan and representative megacities are listed in Table 2. On average, the most abundant water soluble species in $\mathrm{PM}_{2.5}$ were ranked as follows: $\mathrm{SO}_{4}^{2-}$ $\left(23.2 \mu \mathrm{g} \mathrm{m}^{-3}\right), \mathrm{NO}_{3}^{-}\left(18.9 \mu \mathrm{g} \mathrm{m}^{-3}\right), \mathrm{NH}_{4}^{+}\left(12.7 \mu \mathrm{g} \mathrm{m}^{-3}\right), \mathrm{Cl}^{-}$ $\left(5.3 \mu \mathrm{g} \mathrm{m}^{-3}\right)$, and $\mathrm{K}^{+}\left(2.7 \mu \mathrm{g} \mathrm{m}^{-3}\right)$; however, their relative abundances varied with time and their mass accounted for about $40 \%-81 \%$ of total $\mathrm{PM}_{2.5}$. On average, SNA made a large contribution (51.9\%) to $\mathrm{PM}_{2.5}$, which implies that secondary aerosols made a higher contribution to $\mathrm{PM}_{2.5}$, since part of the OC came from secondary emissions.

The annual variation of water soluble species is illustrated in Figs. 3 and 4 . The annual trend of the total sum of water soluble species, which was very similar to $\mathrm{PM}_{2.5}$, decreased slightly from 2008 to 2009 and maintained a relatively constant level between 2009 and 2010 . There was a large decrease from 2010 to 2011, a rebound from 2011 to 2013 , and a significant decrease in 2014 . However, the total concentration of water soluble species in 2013 was still much lower than the values in 2008, 2009 and 2010. The main chemical species of $\mathrm{SO}_{4}^{2-}$, $\mathrm{NO}_{3}^{-}, \mathrm{NH}_{4}^{+}, \mathrm{Cl}$ and $\mathrm{K}$ decreased by respective factors of $65.5 \%, 59.6 \%$, $44.3 \%, 73.9 \%$ and $53.3 \%$ from 2008 to 2014 . Sulfate and $\mathrm{Cl}^{-}$exhibit a similar annual trend to $\mathrm{PM}_{2.5}$ : respective decreases of $65.9 \%, 74.8 \%$ and $84.3 \%$ from 2008 to 2011 ; and prominent increases of $32 \%, 312 \%$ and $126 \%$ from 2011 to 2013 . $\mathrm{K}^{+}$increased through the seven year monitoring, with the exception of a decrease in 2010 and 2011.

The concentration of ss-sulfate (sea salt sulfate) comprised $<5 \%$ of the total sulfate measured, suggesting that sulfate is mainly derived from anthropogenic activities and secondary formation. The average concentrations of $\mathrm{SO}_{4}^{2-}$ in Foshan are comparable with those in Chongqing city, and higher than representative megacities such as Beijing, Guangzhou and Shanghai (Yang et al., 2011b); and lower than the coal-smoke-polluted cities in Western China such as Xi'an (Cao et al., 2012). Similar to Chongqing city, high $\mathrm{SO}_{2}$ emissions, and the specific geographical and meteorological conditions in Foshan, such as the low wind speed (annual average of $2.3 \mathrm{~ms}^{-1}$ ), high temperature (annual average of $22^{\circ} \mathrm{C}$ ) and relative humidity (annual average of 79\%), favor the accumulation of local emissions and formation of sulfate.

$\mathrm{SO}_{4}^{2-}$ was the most abundant species in $\mathrm{PM}_{2.5}$ from 2008 to 2011, and the second highest component in 2012-2014. The contributions of $\mathrm{SO}_{4}^{2-}$ to $\mathrm{PM}_{2.5}$ were $30.5 \%$ and $18.4 \%$ in 2008 and 2014, respectively. Compared to other chemical components, the concentration of sulfate did not change significantly during this interval. $\mathrm{SO}_{2}$ and sulfate decreased by $89 \%$ and $65.5 \%$ from 2008 to 2014 , and their concentrations in 2008 were 5.43 and 2.21 times those in 2014. The decreasing trend of $\mathrm{SO}_{2}$ and sulfate, with average rates of $10.8 \mu \mathrm{g} \mathrm{m}^{-3} \mathrm{yr}^{-1}$ and $4.3 \mu \mathrm{g} \mathrm{m}^{-3} \mathrm{yr}^{-1}$, respectively, may be a consequence of the implementation of environmental action plans or legislation, especially in terms of the regulation of high energy consumption industry, such as the ceramic industry. Their different reduction magnitudes imply that the increase of oxide capacity (NOx and Ozone) would have enhanced the conversion rate of $\mathrm{SO}_{2}$ to sulfate.

Even though the average temperature is relatively high in Foshan, which is a negative factor for the formation of particulate $\mathrm{NO}_{3}^{-}$and $\mathrm{NH}_{4}^{+}$, the levels of $\mathrm{NO}_{3}^{-}$and $\mathrm{NH}_{4}^{+}$were rather higher than those in representative megacities; however, the values are similar to the fraction of nitrate and ammonia in $\mathrm{PM}_{2.5}$ in the neighboring city of Guangzhou. The ratio of nitrate/sulfate has been used as a useful indicator of the relative importance of mobile sources vs. stationary coal combustion sources (Wang et al., 2005). Arimoto et al. (1996) ascribed high nitrate/sulfate ratios to the predominance of mobile sources over stationary sources of pollutants. Here, the average ratios of nitrate/sulfate in $\mathrm{PM}_{2.5}$ varied from 0.24 to 2.62 with an average value of 0.86 , and were $0.73,0.72$, $0.90,0.89,0.92,0.96$ and 0.89 from 2008 to 2014, respectively. There is an increasing trend of nitrate/sulfate ratio, suggesting that the contribution of mobile emissions in Foshan is significantly increasing. However, in general the ratio was $<1$, implying that coal combustion is still a primary source.

\subsubsection{Temporal trend of carbonaceous species}

The average concentrations of OC and EC were $12.9 \mu \mathrm{g} \mathrm{m}^{-3}$ and $5.1 \mu \mathrm{g} \mathrm{m}^{-3}$ (Table 2) - much lower than those in representative megacities, such as the coastal city of Shanghai and the coal-smoke-polluted city of Xi'an. The annual variation of carbonaceous species in Foshan is illustrated in Figs. 3 and 4. The inter-annual trends in the mean values of OC and EC increased between 2008 and 2014 as a whole; however, a significant decrease occurred from 2008 to 2011. The increase in the number of vehicles was probably responsible for the remarkable increase in EC. The OC/EC ratios from different combustion emission

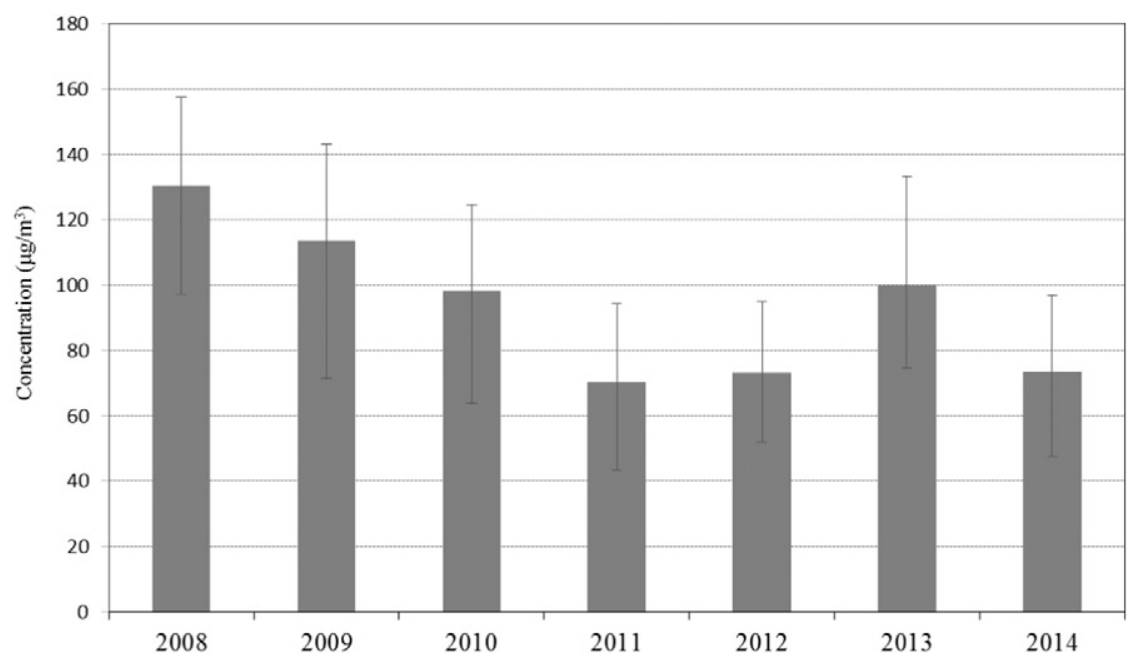

Fig. 2. Annual variation of $\mathrm{PM}_{2.5}$ in Foshan. 
Table 2

Comparison of $\mathrm{PM}_{2.5}$ and chemical compositions at urban sites in representative megacities (units: $\mathrm{ng} / \mathrm{m}^{3}$ for $\mathrm{Cd}, \mathrm{As}$ and $\mathrm{V}, \mu \mathrm{g} / \mathrm{m}^{3}$ for others).

\begin{tabular}{|c|c|c|c|c|c|c|c|}
\hline & $\begin{array}{l}\text { Beijing } \\
\text { (Yang et al., 2011b) }\end{array}$ & $\begin{array}{l}\text { Chongqing } \\
\text { (Yang et al., 2011b) }\end{array}$ & $\begin{array}{l}\text { Shanghai } \\
\text { (Yang et al., 2011b) }\end{array}$ & $\begin{array}{l}\text { Guangzhou } \\
\text { (Yang et al., 2011b) }\end{array}$ & $\begin{array}{l}\text { Chengdu } \\
\text { (Tao et al., 2013) }\end{array}$ & $\begin{array}{l}\text { Xi'an } \\
\text { (Cao et al., 2012) }\end{array}$ & $\begin{array}{l}\text { Foshan } \\
\text { (This study) }\end{array}$ \\
\hline $\mathrm{PM}_{2.5}$ & $118.5 \pm 40.6$ & $129.0 \pm 42.6$ & 67.6 & $81.7 \pm 25.6$ & $119 \pm 56$ & 229 & $113.1 \pm 48.1$ \\
\hline OC & $24.5 \pm 12.0$ & $30.13 \pm 11.0$ & 16.80 & $17.5 \pm 7.6$ & $17 \pm 8$ & 60.2 & $12.9 \pm 13.9$ \\
\hline $\mathrm{EC}$ & $8.19 \pm 5.96$ & $6.39 \pm 2.56$ & 6.49 & $4.1 \pm 2.0$ & $7 \pm 4$ & 14 & $5.1 \pm 2.5$ \\
\hline $\mathrm{SO}_{4}^{2-}$ & $15.8 \pm 10.34$ & $25.6 \pm 9.03$ & 13.00 & $5.6 \pm 2.6$ & $25.0 \pm 14.1$ & 35.3 & $23.2 \pm 13.3$ \\
\hline $\mathrm{NO}_{3}^{-}$ & $10.1 \pm 6.09$ & $5.46 \pm 3.65$ & 5.78 & $12.0 \pm 5.1$ & $10.7 \pm 7.8$ & 17.05 & $18.9 \pm 15.4$ \\
\hline $\mathrm{NH}_{4}^{+}$ & $7.30 \pm 4.17$ & $7.90 \pm 3.78$ & 5.66 & $4.7 \pm 1.7$ & $11.6 \pm 7.3$ & 17.1 & $17.7 \pm 16$ \\
\hline $\mathrm{K}$ & $3.52 \pm 1.77$ & $4.29 \pm 1.65$ & 2.03 & $3.1 \pm 1.15$ & $1.7 \pm 0.8$ & 3.3 & $2.7 \pm 1.9$ \\
\hline $\mathrm{Cl}$ & $2.30 \pm 2.41$ & $1.69 \pm 1.86$ & 6.13 & - & $1.7 \pm 1.7$ & 5.3 & $5.3 \pm 5.3$ \\
\hline $\mathrm{Zn}$ & $0.53 \pm 0.22$ & $0.60 \pm 0.28$ & 0.54 & $1.36 \pm 0.5$ & $0.35 \pm 0.23$ & 1.8 & $2.0 \pm 1.5$ \\
\hline $\mathrm{Mg}$ & $0.29 \pm 0.12$ & $0.28 \pm 0.19$ & 0.18 & - & $0.2 \pm 0.2$ & - & $0.47 \pm 0.28$ \\
\hline $\mathrm{Pb}$ & $0.24 \pm 0.12$ & $0.32 \pm 0.12$ & 0.29 & $0.45 \pm 0.21$ & $0.17 \pm 0.09$ & 1.2 & $0.54 \pm 0.43$ \\
\hline $\mathrm{Ba}$ & $0.21 \pm 0.16$ & $0.26 \pm 0.15$ & - & $0.07 \pm 0.02$ & $0.02 \pm 0.01$ & - & $0.06 \pm 0.05$ \\
\hline Mn & $0.09 \pm 0.03$ & $0.14 \pm 0.07$ & 0.09 & $0.15 \pm 0.07$ & $0.06 \pm 0.04$ & 0.13 & $0.19 \pm 0.11$ \\
\hline $\mathrm{Ti}$ & $0.08 \pm 0.03$ & $0.16 \pm 0.18$ & - & $0.11 \pm 0.09$ & $0.05 \pm 0.03$ & 0.15 & $0.1 \pm 0.11$ \\
\hline $\mathrm{Cu}$ & $0.07 \pm 0.03$ & $0.06 \pm 0.02$ & 0.05 & $0.19 \pm 0.08$ & $0.02 \pm 0.01$ & - & $0.23 \pm 0.19$ \\
\hline $\mathrm{Cd}$ & $50 \pm 30$ & $70 \pm 40$ & - & $20 \pm 10$ & $3.5 \pm 1.9$ & - & $19.3 \pm 15.8$ \\
\hline As & $20 \pm 10$ & $30 \pm 20$ & - & $40 \pm 30$ & $20 \pm 11$ & 80 & $80.5 \pm 55.7$ \\
\hline V & $30 \pm 20$ & $50 \pm 30$ & - & $20 \pm 20$ & $1.7 \pm 0.9$ & - & $39.6 \pm 19.9$ \\
\hline
\end{tabular}

sources may also vary widely. Typical ratios of OC/EC are $0.5,0.75,3.3$ and 7.5 for diesel emissions, road tunnel, biomass burning emissions and motorbikes, respectively (Querol et al., 2013). In this study, except for 2008, the OC/EC ratios (2.19-4.31) generally increased from 2009 to 2014; and the highest secondary organic aerosol $\left(9.62 \mu \mathrm{g} \mathrm{m}^{-3}\right)$, based on the EC trace method (Yang et al., 2011a), occurred in 2013. Therefore, the increase in OC/EC ratios may be due to the increase in oxide capacity resulting from the decrease in motorbike traffic and the increase in other vehicles.

\subsubsection{Temporal trend of inorganic elements}

The total mass of elements accounts for a relatively small fraction $(<20 \%)$ of the total mass of $\mathrm{PM}_{2.5}$ mass (Chan and Yao, 2008); however, they potentially provide insights into the sources of chemical species because of for their uniqueness as tracers and relative stability in the course of atmospheric chemical processes. Twelve elements were selected and they can generally be classified into three groups (Duan et al., 2012): natural (Ti, Ba and Fe), anthropogenic (Pb, As, Bi, Tl and Cd) and natural + anthropogenic ( $\mathrm{Zn}, \mathrm{Cu}, \mathrm{V}$ and $\mathrm{Mn})$.

The concentration of natural elements was in the range of $18 \mathrm{ng} / \mathrm{m}^{3}-$ $2319 \mathrm{ng} / \mathrm{m}^{3}$. The concentrations of elements from natural sources in Foshan are in the range of the values of representative megacities in China (Table 2) and consistent with the values elsewhere. Unlike the anthropogenic elements, the annual variations of natural source components of $\mathrm{PM}_{2.5}$ exhibited a relatively uniform decrease from 2008 to 2014 in Foshan. Compared with other elements, Ti and Ba, regarded as useful indicators of natural sources, exhibit a lower decrease from 2008 to 2014.
The concentrations of Ti and Ba in 2008 were 3.85 and 1.88 times those in 2014, respectively. These findings suggest that control measures during 2008-2014 had little impact on the concentrations of natural elements.

The levels of elements from anthropogenic sources were significantly enhanced in Foshan. The average concentrations of atmospheric $\mathrm{Pb}$, $\mathrm{Zn}, \mathrm{Cu}, \mathrm{Mn}$, As and Cd were $541 \pm 430 \mathrm{ng} / \mathrm{m}^{3}, 2012 \pm 1513 \mathrm{ng} / \mathrm{m}^{3}$, $234 \pm 194 \mathrm{ng} / \mathrm{m}^{3}, 190 \pm 110 \mathrm{ng} / \mathrm{m}^{3}, 80.5 \pm 55.7 \mathrm{ng} / \mathrm{m}^{3}$ and $19.3 \pm$ $15.8 \mathrm{ng} / \mathrm{m}^{3}$ (Table 2), respectively; these values are much higher than the reported average concentrations in China (Duan and Tan, 2013). From 2008 to 2010 the annual variations of elements from anthropogenic sources in $\mathrm{PM}_{2.5}$ were not significant in the case of $\mathrm{Pb}$, while the variations of As and Cd decreased slightly (Fig. 5). From 2011 to 2014 their concentrations dropped significantly, especially in the case of $\mathrm{Zn}$, $\mathrm{Pb}, \mathrm{As}$ and $\mathrm{Cu}$. The concentrations of $\mathrm{Pb}, \mathrm{As}, \mathrm{V}$ and $\mathrm{Cd}$ decreased from 2008 to 2014 by factors of $90.7 \%, 83.5 \%, 86.5 \%$ and $82.4 \%$, respectively. Zn exhibited the largest decrease from 2008 to 2014, and the concentration of $\mathrm{Zn}$ in 2008 was 10.9 times that in 2014. Thus, control measures in Foshan during 2008-2014 had a large effect on the concentrations of elements from anthropogenic sources.

High levels of elements from anthropogenic sources are generally emitted by coal combustion (Duzgoren-Aydin, 2007; Kang et al., 2011; Tian et al., 2010), and part of this group of elements ( $\mathrm{Pb}$ and $\mathrm{Cu}$ ) are also commonly used as ceramic flux to lower the high melting point of silica. Peng et al. (2007) found that the concentrations of Pb were $2870 \mathrm{ng} / \mathrm{m}^{3}$ in the flue gases of ceramic manufacturing in Foshan, and similar values were observed in Spain (Minguillón et al., 2009). Foshan

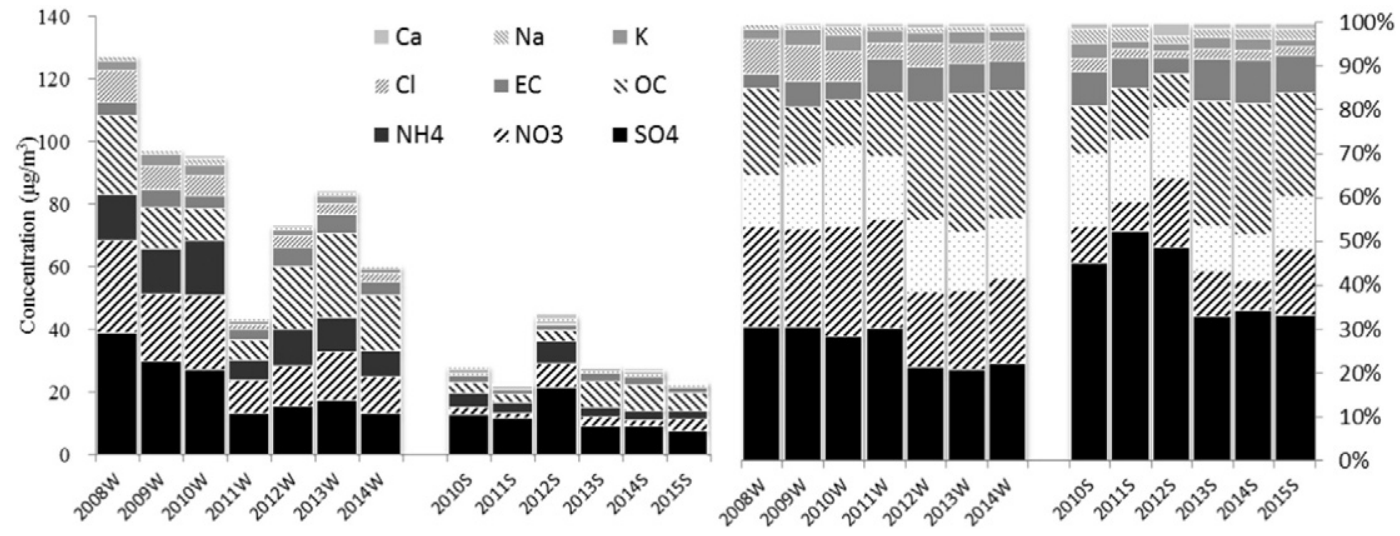

Fig. 3. Annual variation of the main chemical species in $\mathrm{PM}_{2.5}$ in Foshan. 


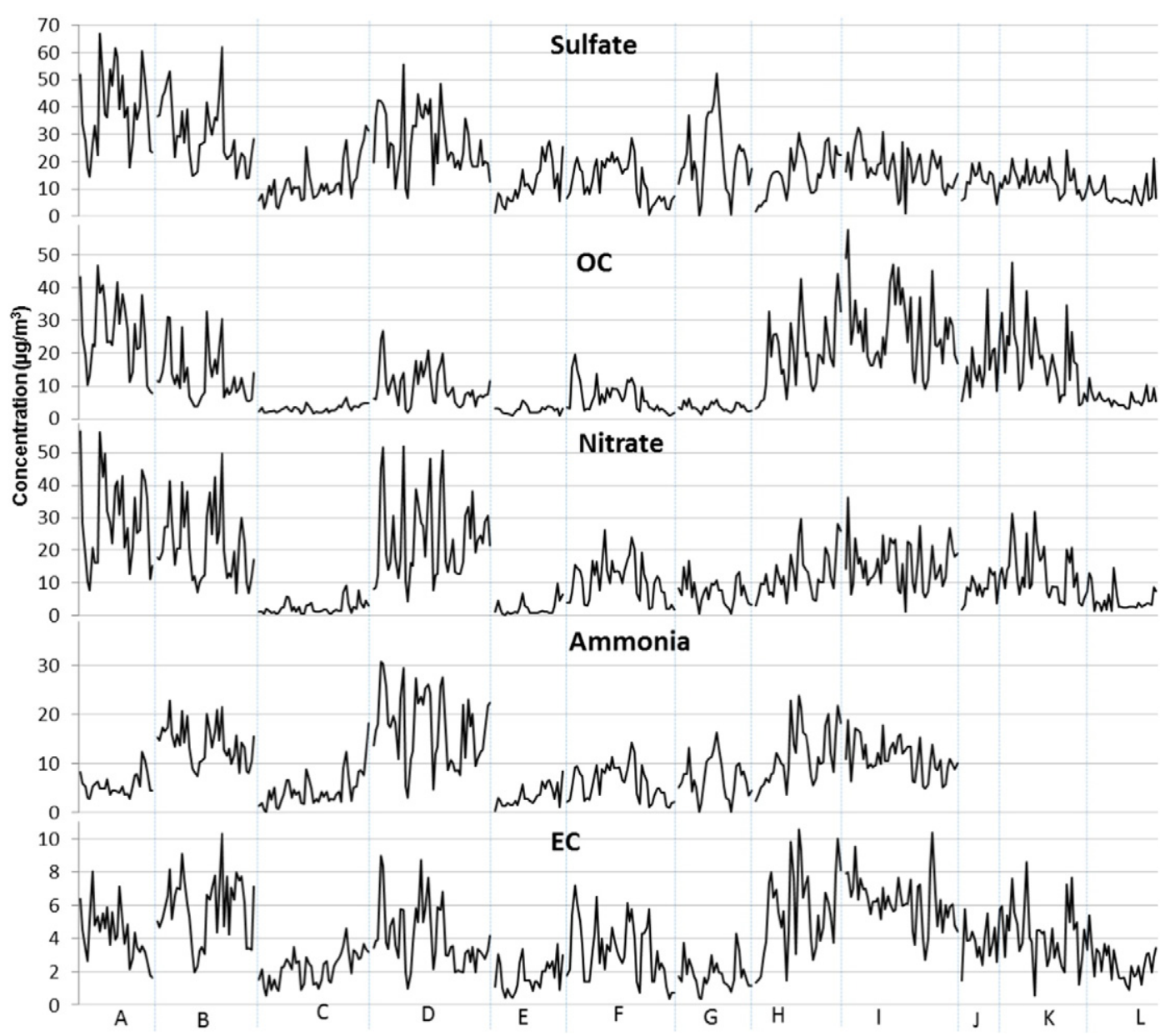

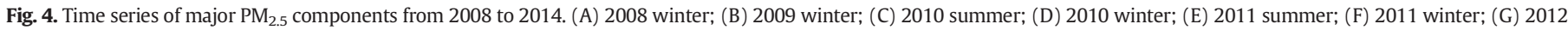
summer; (H) 2012 winter; (I) 2013 winter; (J) 2014 summer; (K) 2014 winter.

is an important manufacturing base in China, with coal as the primary energy source (Shen and Wei, 2012), and the production of ceramics in Foshan city contributes about 30\% to total world production. Therefore, the restriction of coal combustion and the relocation of the ceramic industry from 2007 to 2010 dramatically reduced the emissions of elements from anthropogenic sources.

$\mathrm{Zn}, \mathrm{Cu}, \mathrm{V}$ and $\mathrm{Mn}$ are derived from both natural and anthropogenic sources and have a multi-modal size distribution (coarse and accumulation modes). For the coarse mode, these elements may be derived from crustal soils; however, for the accumulation mode, they may be derived from fossil fuel combustion and vehicle emissions (Duan et al., 2012). In this study, $\mathrm{Zn}$ and $\mathrm{Cu}$ were significantly higher and their annual trend similar to that of elements from anthropogenic sources; however, in contrast, the variation of $\mathrm{V}$ and $\mathrm{Mn}$ was similar to that of natural elements. This demonstrates that $\mathrm{Zn}$ and $\mathrm{Cu}$ could be reduced by control measures in Foshan; however, $\mathrm{V}$ and $\mathrm{Mn}$ could not be controlled effectively.

\subsection{Spatial pattern of air pollutants}

Statistical interpolation (Surfer 11.4, Golden Software) was used to develop a set of spatially interpolated concentration maps for $\mathrm{SO}_{2}$,

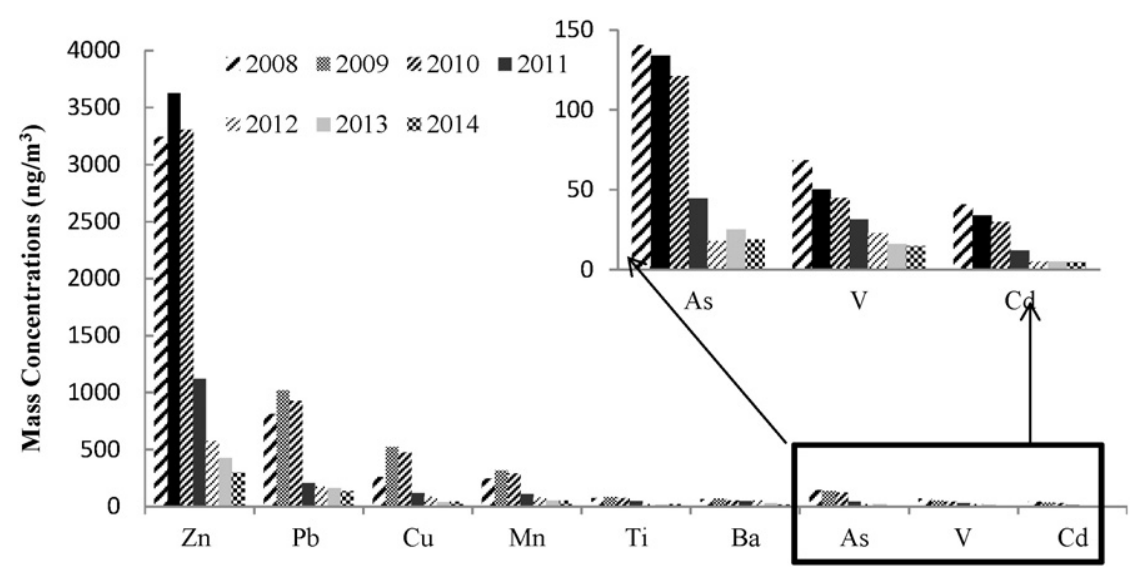

Fig. 5. The annual variation of atmospheric inorganic elements in $\mathrm{PM}_{2.5}$. 
$\mathrm{NO}_{2}$ and $\mathrm{PM}_{2.5}$ in Foshan based on data from the air quality monitoring network (37 stations). The spatial variations of $\mathrm{SO}_{2}, \mathrm{NO}_{2}$ and $\mathrm{PM}_{2.5}$ in Foshan are illustrated in Supplementary Fig. A. $\mathrm{SO}_{2}, \mathrm{NO}_{2}$ and $\mathrm{PM}_{2.5}$ are generally higher in urban areas compared to the surrounding regions, especially in the case of $\mathrm{NO}_{2}$. The variations are likely to reflect locally generated and largely directly emitted $\mathrm{SO}_{2}$ and $\mathrm{NO}_{2}$ at levels above regional contributions. However, $\mathrm{PM}_{2.5}$ variations are more complex: they are slightly attenuated from downtown to rural areas, resulting from the transformation and transport of various regionally-dispersed emissions, including $\mathrm{SO}_{2}$ and $\mathrm{NO}_{2}$.

The average concentrations of the main chemical species in $\mathrm{PM}_{2.5}$ in downtown, urban and rural sites were compared to investigate their spatial variations (Supplement Fig. B). From downtown (CC) to the rural site $(\mathrm{GH})$, the local dominant emission sources in Foshan (Tan et al., 2014b) there was a small decrease in the case of secondary aerosol, such as sulfate and nitrate; a moderate decrease for primary aerosol such as chloride; and a large decrease for both primary and secondary aerosol. The largest contrast between urban and rural concentrations is for chloride, which is mainly from primary sources and its concentrations are the highest when the sampling site is close to the emission source.

In order to quantify the contrasts between sites, the coefficient of divergence $(C D)$, a self-normalizing parameter, was used to compare the distribution of the average concentrations of $\mathrm{PM}_{2.5}, \mathrm{OC}$, EC, inorganic elements and water soluble inorganic species. The CD is calculated as follows:

$\mathrm{CD}_{j k}=\sqrt{\frac{1}{p} \sum_{i=1}^{p}\left(\frac{x_{i j}-x_{i k}}{x_{i j}+x_{i k}}\right)^{2}}$

where $j$ and $k$ are the two sampling sites, $p$ is the number of investigated components, and $x_{i j}$ and $x_{i k}$ are the average mass concentrations of chemical component $i$ at sites $j$ and $k$ (Shen et al., 2011; Tan et al., $2014 b)$. A value close zero indicates that the two sites have very similar levels of pollutants. The $\mathrm{CD}$ values among downtown, urban and rural sites are compared in Table 3. The CD values among six sites were generally higher in summer than in winter, due to the longer suspension time and greater transport distance in winter. The largest $C D$ values were $0.41,0.37$ and 0.34 between $\mathrm{CC}$ and $\mathrm{GH}, \mathrm{SS}$ and $\mathrm{GH}, \mathrm{SD}$ and $\mathrm{GH}$, respectively, and are significantly higher than previous results for Beijing (Tan et al., 2014a). These high values indicate that the chemical species between downtown, urban and rural sites were quite different; however, the difference between downtown and urban sites was not significantly different.

\subsection{Source apportionment}

Carbonaceous species ( $\mathrm{OC}$ and $\mathrm{EC}$ ), water soluble inorganic ions $\left(\mathrm{Na}^{+}, \mathrm{K}^{+}, \mathrm{Mg}^{2+}, \mathrm{Ca}^{2+}, \mathrm{NH}_{4}^{+}, \mathrm{Cl}^{-}, \mathrm{SO}_{4}^{2-}\right.$ and $\left.\mathrm{NO}_{3}^{-}\right)$and inorganic elements ( $\mathrm{Ti}, \mathrm{Zn}, \mathrm{V}, \mathrm{Mn}, \mathrm{Cu}, \mathrm{As}, \mathrm{Rb}, \mathrm{Cd}, \mathrm{Cs}, \mathrm{Ba}, \mathrm{Fe}, \mathrm{Tl}, \mathrm{Pb}, \mathrm{Bi}$ ) were included in the EPA PMF analysis. Among them, $\mathrm{Ca}$ and $\mathrm{Ba}$ are good indicators

Table 3

Coefficient of divergence (CD) values for the six monitoring sites in Foshan during 20082014.

\begin{tabular}{lllllll}
\hline & CC & SS & NH & SD & GM & GH \\
\hline CC & & 0.18 & 0.09 & 0.11 & 0.09 & $\mathbf{0 . 2 9}$ \\
SS & 0.23 & & 0.21 & 0.18 & 0.16 & $\mathbf{0 . 2 6}$ \\
NH & 0.1 & 0.2 & & 0.1 & 0.11 & $\mathbf{0 . 2 2}$ \\
SD & 0.19 & 0.21 & 0.17 & & 0.09 & $\mathbf{0 . 2}$ \\
GM & 0.16 & 0.24 & 0.14 & 0.2 & & 0.18 \\
GH & $\mathbf{0 . 4 1}$ & $\mathbf{0 . 3 7}$ & $\mathbf{0 . 2 9}$ & $\mathbf{0 . 3 4}$ & $\mathbf{0 . 2 7}$ & \\
\hline
\end{tabular}

The $\mathrm{CD}$ values below (above) the dashed line are calculated from summer (winter) data; The values between $\mathrm{GH}$ and other districts are displayed in bold. of dust from crustal sources (Duan et al., 2012); $\mathrm{K}^{+}$is a marker of biomass burning (Duan et al., 2004); As, Pb and $\mathrm{Zn}$ are mainly derived from coal burning and the ceramic industry (Duzgoren-Aydin, 2007; Tian et al., 2010; Peng et al., 2007; Minguillón et al., 2009); and $\mathrm{NH}_{4}^{+}$, $\mathrm{SO}_{4}^{2-}$ and $\mathrm{NO}_{3}^{-}$are indicators of secondary aerosol, Tan et al. (2009a, $2009 b)$ reporting that these species were significantly higher during haze periods.

Five factors (industry, vehicles, dust, secondary aerosol and biomass burning) are identified by PMF5.0, and factor profiles (\% of species total) are illustrated as Fig. 6. Industry (including the ceramic industry and coal combustion), vehicles and dust were the most important sources and respectively contributed $39.2 \%, 20.0 \%$ and $18.4 \%$ of $\mathrm{PM}_{2.5}$ in 2008 (Fig.7). However, secondary aerosol, vehicles and industry (including the ceramic industry and coal combustion) were the three most important sources and contributed $30.5 \%, 23.9 \%$ and $20.1 \%$ of $\mathrm{PM}_{2.5}$ in 2014 , respectively. Compared with 2008, the contribution of vehicles (23.9\%) and biomass burning (11.7\%) increased slightly in 2014. This suggests that the contribution of primary sources (industry and dust) decreased significantly, but secondary sources increased dramatically during the seven year monitoring period in Foshan.

\section{Discussion}

Foshan is situated in the subtropics along the southeast coast of the Chinese mainland and is under the influence of the Asian Monsoon. Air pollution in Foshan exhibits a relatively small degree of spatial variation and a larger seasonal variation. During summer, fresh oceanic air masses and frequent removal of pollutants by rainfall result in significant reductions in air pollution; while in winter, air masses transported to Foshan from the PRD and inland regions will enhance the locally-derived air pollution (Tan et al., 2014a, 2014b). Therefore, the overall concentrations of air pollutants are significantly higher in winter than in summer (Fig. 3). Moreover, even though air pollutants in winter decreased sharply from 2006, no significant difference in pollutant concentration was observed between different summers. Air quality in Foshan has been systematically monitored since the advent of the PRD Regional Air Quality Monitoring Network in 2005, and the annual concentrations of $\mathrm{SO}_{2}, \mathrm{PM}_{10}$, and, $\mathrm{PM}_{2.5}$ decreased by $89 \%, 32 \%$, and $27 \%$ since 2008 , respectively. In this study, $\mathrm{PM}_{2.5}$ decreased dramatically during 20082011, rebounded during 2011-2013, and generally decreased from 2008 to 2014 at an average rate of $8.1 \mu^{-3} \mathrm{~m}^{-3} \mathrm{yr}^{-1}$. Since 2008 , the ambient $\mathrm{PM}_{2.5}$ composition has change dramatically due to air quality control measures. $\mathrm{SO}_{4}^{2-}$ and $\mathrm{NO}_{3}^{-}$were the two highest components of $\mathrm{PM}_{2.5}$ during 2008-2011; however, OC was the highest component of $\mathrm{PM}_{2.5}$ in 2012-2014. These significant reductions are attributable to the implementation of enhanced emission reduction measures; however, different measures have a varying effect on the chemical composition of $\mathrm{PM}_{2.5}$. The results indicate that control measures during 20082014 had a large effect on $\mathrm{Pb}, \mathrm{As}, \mathrm{Cd}, \mathrm{Zn}$ and $\mathrm{Cu}$; water soluble species; and little effect on $\mathrm{V}, \mathrm{Mn}, \mathrm{Ti}, \mathrm{Ba}$ and $\mathrm{Fe}$, and carbonaceous species.

Based on the results of source apportionment, there was a significant change in the source contribution of industries (including the ceramic industry and coal combustion): they were the largest source of $\mathrm{PM}_{2.5}$ in $2008\left(39.2 \%, 51.4 \mathrm{\mu g} \mathrm{m}^{-3}\right)$, but the third most important source in 2012 (21.6\%, $\left.15.8 \mu \mathrm{g} \mathrm{m}^{-3}\right), 2013$ (20.4\%, $20.4 \mu \mathrm{g} \mathrm{m}^{-3}$ ) and 2014 $\left(20.1 \%, 14.8 \mu \mathrm{g} \mathrm{m}^{-3}\right)$. Their relative contribution to $\mathrm{PM}_{2.5}$ decreased significantly from $39.2 \%$ to $20.1 \%$ and their contribution to the reduction of $\mathrm{PM}_{2.5}$ was $36.6 \mu \mathrm{g} \mathrm{m}^{-3}$, accounting for $64.2 \%$ of the total $\mathrm{PM}_{2.5}$ reduction. This decreasing trend illustrates that the efficacy of industrial emission control measures adopted in Foshan. On a national scale, the implementation of stringent desulfurization measures in power plants during the 11th five-year plan (2006-2010) significantly decreased $\mathrm{SO}_{2}$ emissions. The reductions also reflected other sulfur control measures implemented on a regional scale by "the PRD Clean Air Action Plan" since 2010. For primary particles, particulate matter control devices were installed for cement plants and industrial boilers; and stricter 

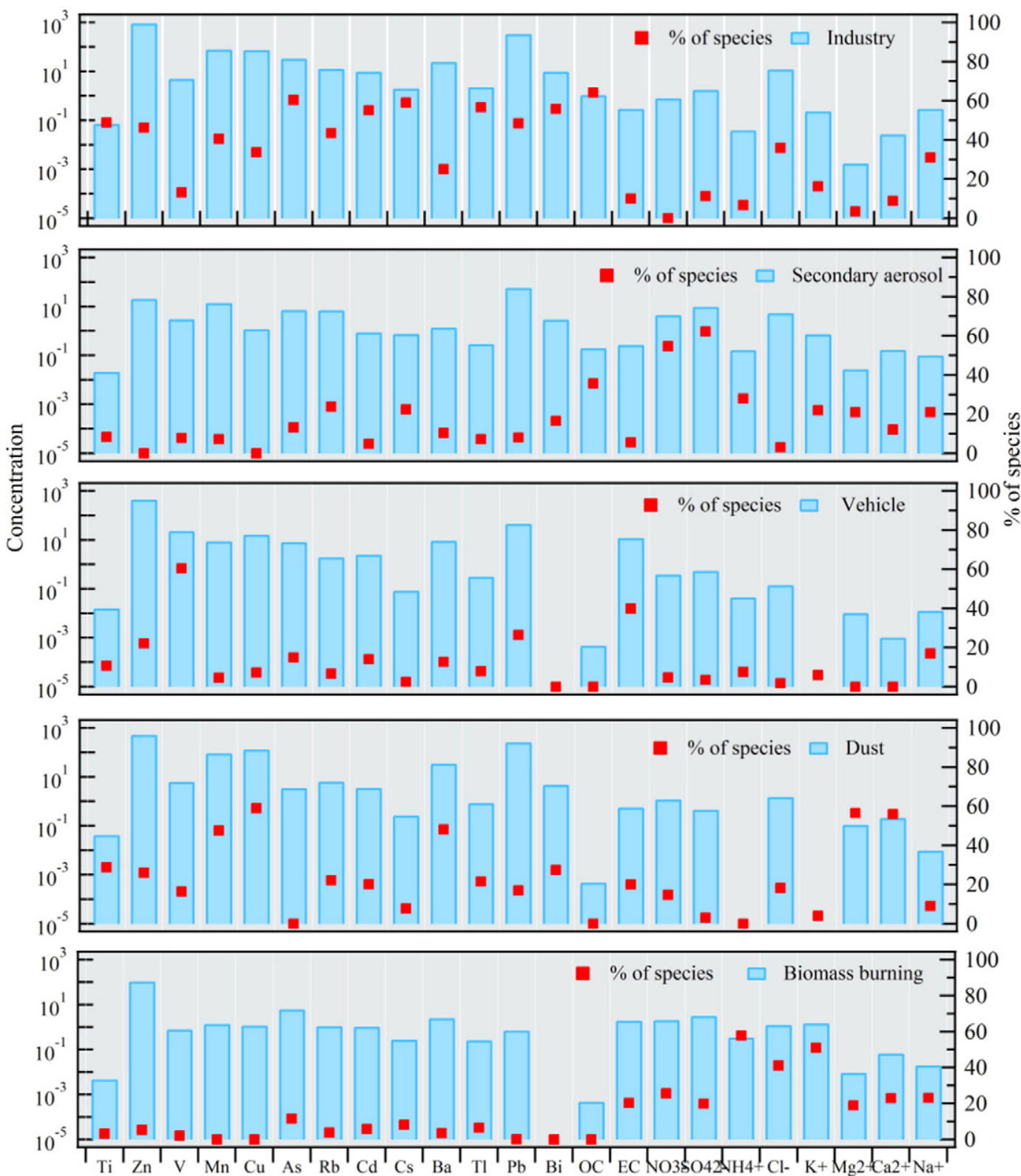

Fig. 6. Factor profiles (\% of species total) obtained from the EPA PMF5.0 model.

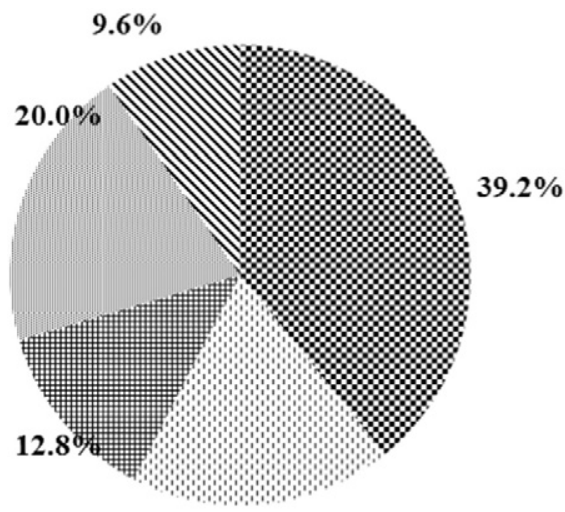

$18.4 \%$

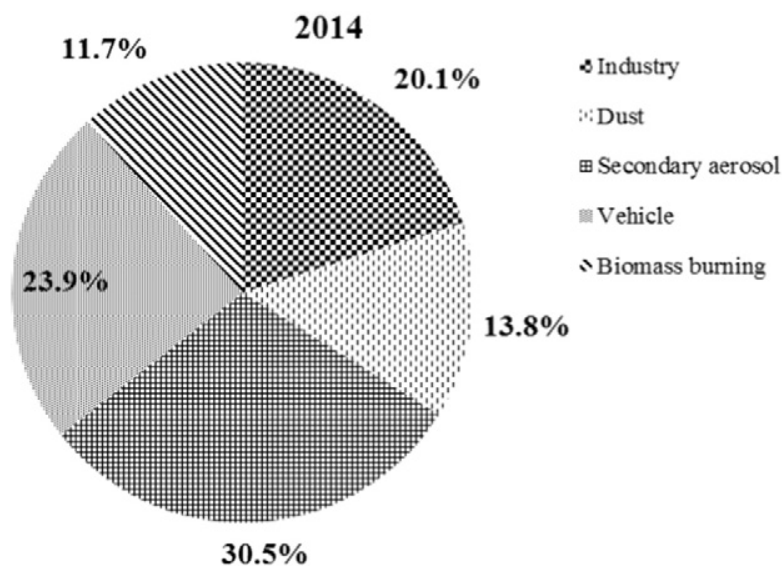

Fig. 7. Source apportionment for $\mathrm{PM}_{2.5}$ in 2008 and 2014 in Foshan. 
emissions standards were established for air pollutants produced by boilers. On a city scale, control measures were applied to improve the air quality and reduce air pollution in preparation for the 16th Asian Games and the program of "national environmental protection model city" from 2008 to 2011. Coal combustion is one of Foshan's largest sources of air pollution (Tan et al., 2014b). Characterized by high energy consumption and serious pollution, the ceramic industry has caused major environmental problems in Foshan city (Tan et al., 2014b), with $48.16 \%, 45.92 \%, 91.3 \%$, and $8.3 \%$ of $\mathrm{SO}_{2}$, NOx, dust and smoke being emitted by ceramic industry in Foshan city, respectively. $>400$ ceramic enterprises were closed or relocated and small coal-fired boilers below 4 tonnes were eliminated in 2008, which reduced emissions by 2600 tonnes for $\mathrm{SO}_{2}$ and 800 tonnes for dust. Since the implementation of the tightened regulation of the ceramics industry, the concentration of $\mathrm{SO}_{2}, \mathrm{NOx}$ and $\mathrm{PM}_{10}$ decreased by $23 \%, 12 \%$ and $7.5 \%$ from 2008 to 2009 , respectively. However, the cause of the rebound of $\mathrm{PM}_{2.5}$ from 2011 was not the weakening of the supervisory efforts of the government, but rather the shifting of atmospheric environmental issues from air pollution dominated by primary sources to complex pollution (dominated by both primary and secondary emissions).

Even though the relative contribution of vehicle emissions to $\mathrm{PM}_{2.5}$ increased from $20 \%$ to $23.1 \%$, the mass contribution decreased from $26.1 \mathrm{~g} \mathrm{~m}^{-3}$ to $16.9 \mathrm{gg} \mathrm{m}^{-3}$. During the monitoring period, the National IV standards for new vehicles and National III standards for motorcycles were upgraded for motor vehicle emissions standards before $1 / 1 / 2011$; and YUE IV standards were implemented to regulate the quality of vehicle fuel before 12/31/2011. With regard to vehicle emission controls, since 2009 Foshan has implemented the vehicular exhaust emission measurement method under simple driving mode conditions. Road use restriction measures for "non-green-label vehicles" have been further enhanced since 1 July 2009.

Among these abatements, dust control exhibits the second largest contribution to $\mathrm{PM}_{2.5}$ improvements in Foshan. The relative contribution to $\mathrm{PM}_{2.5}$ from dust decreased from $18.4 \%$ to $13.8 \%$ and the concentration from dust decreased from $24.0 \mu \mathrm{g} \mathrm{m}^{-3}$ to $10.1 \mu \mathrm{g} \mathrm{m} \mathrm{m}^{-3}$ for the monitoring period, on average. Long-term dust control measures contributed a reduction of $>13.9 \mu \mathrm{g} \mathrm{m}^{-3}$ to the $\mathrm{PM}_{2.5}$ level in Foshan. Since the Asian Games the local government has strengthened controls on dust emissions by reducing dust from building construction (via strict environmental standards for construction site management and by reducing construction sites in heavy pollution episodes) and by reducing road dust (via increased mechanical cleaning and washing). In addition, the reduction of industrial sources has also contributed to dust abatement.

The contribution from biomass burning was relatively constant from 9.6\% $\left(12.5 \mu \mathrm{g} \mathrm{m}^{-3}\right)$ to $11.7 \%\left(8.6 \mu \mathrm{g} \mathrm{m}^{-3}\right)$ during the measurement period. Although the concentration was reduced slightly, the relative contribution to $\mathrm{PM}_{2.5}$ increased slightly, which due to the reduction of other source. In contrast to the reduction in primary pollutant emissions, the contribution of secondary pollutants to $\mathrm{PM}_{2.5}$ increased from $12.8 \%$ $\left(16.6 \mu \mathrm{g} \mathrm{m}^{-3}\right)$ to $31.6 \%\left(23.2 \mu \mathrm{g} \mathrm{m}^{-3}\right)$ during the measurement period. This was probably due to differences in the reduction of its precursors, NOx and VOC. The increase in $\mathrm{O}_{3}$ demonstrates the ineffectiveness of a single pollutant control model in mitigating secondary pollutants without executing holistic air quality control measures.

The control measures all had a major effect on the reduction of $\mathrm{PM}_{2.5}$ in Foshan; however, the strictest air pollution control measures were taken in order to improve air quality in preparation for the 16th Asian Games in 2010. The largest reduction of $\mathrm{PM}_{2.5}$ occurred in 2011, rather than in 2010, mainly because the impact of air quality policy on $\mathrm{PM}_{2.5}$ lagged behind the promulgation of the measures; control measures were applied inconsistently in 2010, but became routine by 2011 . The rebound in $\mathrm{PM}_{2.5}$ in Foshan since 2011 is mainly because of the dramatic increase in the number of road vehicles, the enhancement of oxide capacity and the worsening of regional pollution. Since 2012, Zhaoqin, to the west of Foshan city, has become the most polluted city in the PRD. Therefore, vehicle emissions control (NOx and VOC) and regional transportation mechanisms for overall regional air quality management are crucial for the reduction of $\mathrm{PM}_{2.5}$.

\section{Conclusions}

Air pollutants, including $\mathrm{SO}_{2}, \mathrm{NO}_{2}, \mathrm{O}_{3}$ and $\mathrm{PM}_{2.5}$, chemical compositions of $\mathrm{PM}_{2.5}$, were measured synchronously from 2008 to 2014. $\mathrm{PM}_{2.5}$ and most of the chemical species generally decreased due to the implementation of pollution control measures. Control measures implemented during 2008-2014 had a large effect on anthropogenic elements ( $\mathrm{Pb}$, $\mathrm{As}, \mathrm{Cd}, \mathrm{Zn}$ and $\mathrm{Cu}$ ) and water soluble species, but had little influence on crustal elements (V, Mn, Ti, Ba and Fe) and carbonaceous species. From 2008 to $2014, \mathrm{SO}_{2}$ and sulfate decreased by $89 \%$ and $65.5 \%$, respectively; and their concentrations in 2008 were 6.21 and 2.70 times those in 2014. $\mathrm{SO}_{4}^{2-}$ and $\mathrm{NO}_{3}^{-}$were the two largest components of $\mathrm{PM}_{2.5}$ in 2008-2011; however, OC was the largest component in $\mathrm{PM}_{2.5}$ from 2012 to 2014. The ceramic industry and coal combustion were the largest source of $\mathrm{PM}_{2.5}$ in 2008 (39.2\%, $\left.51.4 \mu \mathrm{g} \mathrm{m}^{-3}\right)$, but the third most important source in $2014\left(20.1 \%, 14.8 \mu \mathrm{g} \mathrm{m}^{-3}\right)$. Their relative contribution to $\mathrm{PM}_{2.5}$ decreased significantly from $39.2 \%$ to $20.1 \%$ and their contribution to the reduction of $\mathrm{PM}_{2.5}$ was $36.6 \mu \mathrm{g} \mathrm{m}^{-3}$, accounting for $64.2 \%$ of the total $\mathrm{PM}_{2.5}$ reduction. This decreasing trend demonstrates the efficacy of the industrial emission control measures adopted in Foshan. Dust control exhibits the second largest contribution to $\mathrm{PM}_{2.5}$ improvements. The relative contribution to $\mathrm{PM}_{2.5}$ from dust decreased from $18.4 \%$ to $13.8 \%$ and the concentration from dust decreased from $24.0 \mu \mathrm{g} \mathrm{m} \mathrm{m}^{-3}$ to $10.1 \mu \mathrm{g} \mathrm{m}{ }^{-3}$ during the monitoring period. In contrast to the reduction in primary pollutant emissions, the contribution of secondary pollutants to $\mathrm{PM}_{2.5}$ increased from $12.8 \%\left(16.6 \mu \mathrm{g} \mathrm{m}^{-3}\right)$ to $31.6 \%\left(23.2 \mu \mathrm{g} \mathrm{m}^{-3}\right)$ during the measurement period. This suggests that the contribution of primary sources decreased significantly, but secondary sources increased dramatically during the seven year measurement period. Therefore, vehicle emission controls and the establishment of regional mechanisms for overall regional air quality management are crucial for the reduction of $\mathrm{PM}_{2.5}$. The results of this study demonstrate that the continuous monitoring of the chemical species of $\mathrm{PM}_{2.5}$ can be used to evaluate the effectiveness of the control measures and policies, and that it is an important component of air quality monitoring control policy.

\section{Acknowledgments}

We thank the National Natural Scientific Foundation of China (grant nos. 41475116, 41105111; no.41275134) for financial support. We also appreciate the valuable advice from the editor which great improved the manuscript.

\section{References}

Arimoto, R., Duce, R.A., Savoie, D.L., Prospero, J.M., Talbot, R., Cullen, J.D., Tomza, U., Lewis, N.F., Ray, B.J., 1996. Relationships among aerosol constituents from Asia and the North Pacific during PEM-West A. J. Geophys. Res 101 (D1), 2011-2023.

Cao, J.J., Lee, S.C., Ho, K.F., Zhang, X.Y., Zou, S.C., Fung, K., Chow, J.C., Watson, J.G., 2003. Characteristics of carbonaceous aerosol in Pearl River Delta Region, China during 2001 winter period. Atmos. Environ. 37, 1451-1460.

Cao, J.J., Lee, S.C., Ho, K.F., Zou, S.C., Fung, K., Li, Y., Watson, J.G., Chow, J.C., 2004. Spatial and seasonal variations of atmospheric organic carbon and elemental carbon in Pearl River Delta Region, China. Atmos. Environ. 38, 4447-4456.

Cao, J.J., Shen, Z.X., Chow, J.C., Watson, J.G., Lee, S.C., Tie, X.X., Ho, K.F., Wang, G.H., Han, Y.M., 2012. Winter and summer $\mathrm{PM}_{2.5}$ chemical compositions in fourteen Chinese cities. J. Air Waste Manage. Assoc. 62, 1214-1226.

Chan, C.K., Yao, X., 2008. Air pollution in mega cities in China. Atmos. Environ. 42, 1-42.

Cheng, Y., He, K.B., Duan, F.K., Zheng, M., Ma, Y.L., Tan, J.H., Du, Z.Y., 2010. Improved measurement of carbonaceous aerosol: evaluation of the sampling artifacts and intercomparisoan of the thermal-optical analysis methods. Atmos. Chem. Phys. 10, 8533-8548.

Chow, J., Watson, J., Chen, L., Chang, M., Robinson, N., Trimble, D., Kohl, S., 2007. The IMPROVE-a temperature protocol for thermal/optical carbon analysis: maintaining consistency with a long-term database. J. Air Waste Manag. Assoc. 57, 1014-1023.

Duan, J.C., Tan, J.H., 2013. Atmospheric heavy metals and arsenic in China: situation, sources and control policies. Atmos. Environ. 74, 93-101. 
Duan, F.K., Liu, X.D., Yu, T., Cachier, H., 2004. Identification and estimate of biomass burning contribution to the urban aerosol organic carbon concentrations in Beijing. Atmos. Environ. 38, 1275-1282.

Duan, J.C., Tan, J.H., Cheng, D.X., Bi, X.H., Deng, W.J., Sheng, G.Y., Fu, J.M., Wong, M.H., 2007. Sources and characteristics of carbonaceous aerosol in two largest cities in Pearl River Delta Region, China. Atmos. Environ. 41, 2895-2903.

Duan, J., Tan, J., Wang, S., Hao, J., Chai, F., 2012. Size distributions and sources of elements in particulate matter at curbside, urban and rural sites in Beijing. J. Environ. Sci. 24, 87-94.

Duan, J.C., Tan, J.H., Hao, J.M., Chai, F.H., 2014. Size distribution, characteristics and sources of heavy metals in haze episod in Beijing. J. Environ. Sci. 26, 189-196.

Duzgoren-Aydin, N.S., 2007. Sources and characteristics of lead pollution in the urban environment of Guangzhou. Sci. Total. Environ. 385, 182-195.

Gens, A., Hurley, J.F., Tuomisto, J.T., Friedrich, R., 2014. Health impacts due to personal exposure to fine particles caused by insulation of residential buildings in Europe. Atmos. Environ. 84, 213-221.

Hagerman, I., Isaxon, C., Gudmundsson, A., Wierzbicka, A., Dierschke, K., Berglund, M., Pagels, J., Nielsen, J., Assarsson, E., Andersson, U.B.K., Xu, Y.Y., Jonsson, B.A.G., Bohgard, M., 2014. Effects on heart rate variability by artificially generated indoor nano-sized particles in a chamber study. Atmos. Environ. 88, 165-171.

He, K.B., Yang, F.M., Ma, Y.L., Zhang, Q., Yao, X.H., Chan, C.K., Cadle, S., Chan, T., Mulawa, P., 2001. The characteristics of $\mathrm{PM}_{25}$ in Beijing China. Atmos. Environ. 35, 4959-4970.

Kang, Y., Liu, G.J., Chou, C.L., Wong, M.H., Zheng, L.G., Ding, R., 2011. Arsenic in Chinese coals: distribution, modes of occurrence, and environmental effects. Sci. Total Environ. 412, 1-13.

Keene, W.C., Moody, J.L., Galloway, J.N., Prospero, J.M., Cooper, O.R., Eckhardt, S., Maben, J.R., 2014. Long-term trends in aerosol and precipitation composition over the western North Atlantic Ocean at Bermuda. Atmos. Chem. Phys. 14, 8119-8135.

Lin, H.L., Zhang, Y.H., Liu, T., Xiao, J.P., Xu, Y.J., Xu, X.J., Qian, Z.M., Tong, S.L., Luo, Y., Zeng, W.L., Ma, W.J., 2014. Mortality reduction following the air pollution control measures during the 2010 Asian Games. Atmos. Environ. 91, 24-31.

Liu, X., Cheng, Y., Zhang, Y., Jung, J., Sugimoto, N., Chang, S., Kim, Y., Fan, S., Zeng, L., 2008. Influences of relative humidity and particle chemical composition on aerosol scattering properties during the 2006 PRD campaign. Atmos. Environ. 42, 1525-1536.

Minguillón, M.C., Monfort, E., Querol, X., Alastuey, A., Celades, I., Miró, J.V., 2009. Effect of ceramic industrial particulate emission control on key components of ambient $\mathrm{PM}_{10}$. J. Environ. Manag. 90, 2558-2567.

Paatero, P., 2004. User's guide for positive matrix factorization programs PMF2 and PMF3, part 1: tutorial. Department of Physics, Finland (University of Helsinki).

Paatero, P., Tapper, U., 1994. Positive matrix factorization: a non-negative factor model with optimal utilization of error estimates of data values. Environmetrics 5, 111-126.

Peng, S.J., Ouyang, X.J., Li, D.J., Yi, Z.G., 2007. Metal elements in Tsp form ambient air of different ceramic workshops in Foshan. Earth Environ. 1, 011.

Polissar, A.V., Hopke, P.K., Paatero, P., Malm, W.C., Sisler, J.F., 1998. Atmospheric aerosol over Alaska: 2. Elemental composition and sources. J. Geophys. Res. 103 (D15), 19045-19057.

Querol, X., Alastuey, A., Moreno, T., Viana, M.M., Castillo, S., Pey, J., Rodriguez, S., Artinano, B., Salvador, P., Sanchez, M., Dos Santos, S.G., Garraleta, M.D.H., Fernandez-Patier, R., Moreno-Grau, S., Negral, L., Minguillon, M.C., Monfort, E., Sanz, M.J., Palomo-Marin,
R., Pinilla-Gil, E., Cuevas, E., de la Rosa, J., de la Campa, A.S., 2008. Spatial and temporal variations in airborne particulate matter $\left(\mathrm{PM}_{10}\right.$ and $\left.\mathrm{PM}_{2.5}\right)$ across Spain 1999-2005. Atmos. Environ. 42, 3964-3979.

Querol, X., Alastuey, A., Viana, M., Moreno, T., Reche, C., Minguillón, M.C., Ripoll, A. Pandolfi, M., Amato, F., Karanasiou, A., Pérez, N., 2013. Variability of carbonaceous aerosols in remote, rural, urban and industrial environments in Spain: implications for air quality policy. Atmos. Chem. Phys. 13, 6185-6206.

Shen, J., Wei, C., 2012. Relocation mechanisms of the ceramics industry impacted by the environmental regulations in Foshan City. Acta Geograph. Sin. 67, 467-478.

Shen, Z.X., Cao, J.J., Liu, S.X., Zhu, C.S., Wang, X., Zhang, T., Xu, H.M., Hu, T.F., 2011. Chemical composition of $\mathrm{PM}_{10}$ and $\mathrm{PM}_{2.5}$ collected at ground level and 100 meters during a strong winter-time pollution episode in Xi'an, China. J. Air Waste Manag. Assoc. 61, 1150-1159.

Sun, Y., Zhuang, G., Tang, A., Wang, Y., An, Z., 2006. Chemical characteristics of $\mathrm{PM}_{2.5}$ and $\mathrm{PM}_{10}$ in haze-fog episodes in Beijing. Environ. Sci. Technol. 40, 3148-3155.

Tan, J.H., Duan, J.C., Chen, D.H., Wang, X.H., Guo, S.J., Bi, X.H., Sheng, G.Y., He, K.B., Fu, J.M., 2009a. Chemical characteristics of haze during summer and winter in Guangzhou. Atmos. Res. 94, 238-245.

Tan, J., Duan, J., He, K., Ma, Y., Duan, F., Chen, Y., Fu, J., 2009b. Chemical characteristics of $\mathrm{PM}_{2.5}$ during a typical haze episode in Guangzhou. J. Environ. Sci. 21, 774-781.

Tan, J.H., Duan, J.C., Chai, F.H., He, K.B., Hao, J.M., 2014a. Source apportionment of size segregated fine/ultrafine particle by PMF in Beijing. Atmos. Res. 139, 90-100.

Tan, J.H., Duan, J.C., Ma, Y.L., Yang, F.M., Cheng, Y., He, K.B., Yu, Y.C., Wang, J.W., 2014b. Source of atmospheric heavy metals in winter in Foshan, China. Sci. Total. Environ. 493, 262-270.

Tang, X.L., Bi, X.H., Sheng, G.Y., Tan, J.H., Fu, J.M., 2006. Seasonal variation of the particle size distribution of n-alkanes and polycyclic aromatic hydrocarbons (PAHs) in urban aerosol of Guangzhou, China. Environ. Monit. Assess. 117, 193-213.

Tao, J., Cheng, T., Zhang, R., Cao, J., Zhu, L., Wang, O., Luo, L., Zhang, L., 2013. Chemical composition of PM2.5 at an urban site of Chengdu in southwestern China. Adv. Atmos. Sci. 30, 1070-1084.

Tian, H.Z., Wang, Y., Xue, Z.G., Cheng, K., Qu, Y.P., Chai, F.H., Hao, J.M., 2010. Trend and characteristics of atmospheric emissions of $\mathrm{Hg}$, As, and Se from coal combustion in China, 1980-2007. Atmos. Chem. Phys. 10, 11905-11919.

Wang, G., Huang, L., Gao, S., Gao, S., Wang, L., 2002. Characterization of water-soluble species of $\mathrm{PM}_{10}$ and $\mathrm{PM}_{2.5}$ aerosols in urban area in Nanjing, China. Atmos. Environ. 36, 1299-1307.

Wang, Y., Zhuang, G., Tang, A., Yuan, H., Sun, Y., Chen, S., Zheng, A., 2005. The ion chemistry and the source of PM2.5 aerosol in Beijing. Atmos. Environ. 39 (21), 3771-3784.

Yang, F., Huang, L., Duan, F., Zhang, W., He, K., Ma, Y., Brook, J.R., Tan, J., Zhao, Q., Cheng, Y., 2011a. Carbonaceous species in $\mathrm{PM}_{2.5}$ at a pair of rural/urban sites in Beijing, 20052008. Atmos. Chem. Phys. 11, 7893-7903.

Yang, F., Tan, J., Zhao, Q., Du, Z., He, K., Ma, Y., Duan, F., Chen, G., 2011b. Characteristics of $\mathrm{PM}_{2.5}$ speciation in representative megacities and across China. Atmos. Chem. Phys. $11,5207-5219$.

Zhang, Z.Q., Friedlander, S.K., 2000. A comparative study of chemical databases for fine particle Chinese. Environ. Sci. Technol. 34, 4687-4694. 